\section{Board certification in Japan: corruption and near-collapse of reform}

The board certification system in Japan is undergoing reform, but it is likely to be watered down without significant improvement.

Traditionally, Japanese doctors had not given weight to board certification. Instead, they used to attach a high value in obtaining academic credentials such as a doctor's degree $(\mathrm{PhD})$ by entering graduate schools. Until the 1990s, almost all doctors went through postgraduate training at university hospitals after graduation and these hospitals tended to be more academic than clinical. This tendency resulted in a lack of clinical skills among Japanese doctors. ${ }^{1}$ Because of the criticism that Japanese doctors lack clinical competence, the Ministry of Health, Labour, and Welfare in Japan mandated all doctors to have 2 years of official postgraduate clinical training beginning in 2004, either at university hospitals or at other community hospitals. ${ }^{2}$ As a result, more than half of the medical students that graduated elected to have training outside medical schools, attaching more weight on improving clinical skills, which was felt to be more difficult to achieve at university hospitals.

With the shift towards more interest in improving clinical competency, rather than academic achievements mainly in basic science, more young doctors now want board certifications instead of $\mathrm{PhD}$ degrees. Board certification in Japan began in 1962 , but its quality has not been validated. It is usually provided by the society of a given subspecialty, and tends to be easy to obtain, and most programmes do not keep up with the expected clinical competency. In addition, many board certifications run by subspecialty societies require candidates to pay a membership fee to them, to attend annual meetings with certain poster/oral presentations, or publications of articles to the journal these societies publish. In short, academic societies running board certification systems and those candidates to be certified had significant conflicts of interest.

To unify and improve the standard of each specialty, the Japanese Board of Medical Specialties (J-BMS) was established in 2003. It aimed to establish high standards for physician specialty certification, requiring formal clinical training for doctors to be certified. It also tried to be an independent third party to avoid the conflicts of interest described above. ${ }^{3}$

However, the J-BMS was bombarded with criticism from many because the reform might attract doctors to big cities to have training to be specialists, and it could result in a lack of physicians in rural areas. Also, societies felt that they were deprived by the J-BMS of the authoritative power of providing board certification to their members. Because of these criticisms, many executive board members of the J-BMS were forced to resign including Yasuo Ikeda, who was the executive head at that time.

The new executive board members drafted a guideline on the new board certification, which was very disappointing. The guideline highlighted the importance of flexibility in regards to the relationship with other medical societies. In fact, the J-BMS simply compromised them to keep the status quo of society members becoming specialists easily, so that they can make society members happy. It even gave up on demanding subspecialty societies have training programmes. Instead, it allowed them to have curriculums to follow, so that doctors can be subspecialists without formal clinical training. To make matters even worse, the J-BMS is now given money to run by these academic societies. ${ }^{4}$ The relationship between academic societies and the J-BMS is not sound and the J-BMS does not keep the independence from these societies it originally aimed at. The J-BMS works for the interest of these societies, not for its specialist candidates, not to mention the people of Japan.

No board certification system is perfect. The American Board of Internal Medicine was recently criticised for placing too much emphasis on the maintenance of certification activities. ${ }^{5}$ It is clear that there needs to be a balance between the assurance of clinical competencies among specialists and its burden. Having stated it, the J-BMS will continue to engender incompetent specialists in Japan and will significantly compromise the quality of healthcare in this country. I believe that only a third-party audit by bodies outside Japan, like ACGME International, which has no conflicts of interest with these academic societies, can solve this problem. ${ }^{6}$ Japanese medical societies, including the J-BMS, have no capability of self-regulation.

\section{Kentaro Iwata, ${ }^{1}$ Daniel J Mosby, ${ }^{1}$ Michiko Sakane ${ }^{2}$}

'Division of Infectious Diseases, Kobe University Hospital, Kobe, Japan

${ }^{2}$ Sakane M Clinic, Tsukuba, Japan

Correspondence to Professor Kentaro Iwata, Division of Infectious Diseases, Kobe University Hospital, Kusunokicho 7-5-2, Chuoku, Kobe, Hyogo 6500017, Japan; kentaroiwata1969@gmail.com

Contributors KI drafted the letter and DJM and MS read, edited and corrected the content. All authors agreed with the final manuscript before submission.

Competing interests None declared.

Provenance and peer review Not commissioned; externally peer reviewed.

\section{(1) OPEN ACCESS}

Open Access This is an Open Access article distributed in accordance with the Creative Commons Attribution Non Commercial (CC BY-NC 4.0) license, which permits others to distribute, remix, adapt, build upon this work non-commercially, and license their derivative works on different terms, provided the original work is properly cited and the use is noncommercial. See: http://creativecommons.org/licenses/ by-nc/4.0/

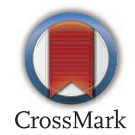

To cite Iwata K, Mosby DJ, Sakane M. Postgrad Med J 2017;93:436.

Accepted 13 April 2017

Published Online First 10 May 2017

Postgrad Med J 2017;93:436.

doi:10.1136/postgradmedj-2017-134994

(c) Article author(s) (or their employer(s) unless otherwise stated in the text of the article) 2017. All rights reserved. No commercial use is permitted unless otherwise expressly granted.

\section{REFERENCES}

1 Yano E, Yamaoka K, Sugita S, et al. Comparing postgraduate medical education at university and nonuniversity hospitals in Japan. Acad Med 1992;67:54-8.

2 Nomura K, Yano E, Aoki M, et al. Improvement of residents' clinical competency after the introduction of new postgraduate medical education program in Japan Med Teach 2008;30:e161-e169.

3 Ikeda Y. Current status of Medical Board in Japan. http://medtrain.umin.jp/record/pdf_doc/20081009_ sennmonnihyoukaninteikikou.pdf (accessed 8 Jan 2017).

4 Records of meeting. Board meeting of J-BMS [in Japanese]. (accessed 23 Feb 2017)

5 Baron RJ, Braddock CHI. Knowing what we Don't Know-Improving Maintenance of Certification. N Engl J Med 2016;375:2516-7.

6 ACGME International. http://www.acgme-i.org/ (accessed 23 Feb 2017) 